\section{Moruf Akanni Adebakin}

https://orcid.org/0000-0001-5142-0820

Department of Business Administration and Management

School of Management and Business Studies

\section{Samuel Essien Okon}

https://orcid.org/0000-0002-1661- 7203

Department of Business Administration

Faculty of Management Sciences

University of Lagos, Nigeria

Yaba College of Technology, Lagos, Nigeria okonsamuel1212@gmail.com moruf.adebakin@yabatech.edu.ng

\title{
Procedural justice, job satisfaction and organisational citizenship behaviour within small and medium scale enterprises in Nigeria
}

Accepted by Editor Ewa Ziemba | Received: April 12, 2019 | Revised: August 19, 2019; October 13, 2019 | Accepted: October 21, 2019.

\begin{abstract}
Aim/purpose - This study aims at investigating the incidence of procedural justice, job satisfaction, and organisational citizenship behaviour (OCB) of employees within small and medium scale enterprises (SMEs) in Nigeria. The main thrust of the study is to provide justification for the possible link between these behavioural factors with a view to establishing their roles in fostering SMEs.

Design/methodology/approach - A cross-sectional survey design was employed to elicit information from 1420 employees randomly selected from 71 surveyed companies. The responses from the questionnaire were analysed employing correlation and hierarchical regression analysis.

Findings - The result showed a significant relationship between procedural justice, job satisfaction, and OCB after controlling for age and gender. The study, therefore, concludes that procedural justice, job satisfaction and citizenship behaviour of SMEs employees are imperative for the success and ultimate survival of SMEs.

Research implications/limitations - Understanding the impediments to the growth of SMEs in developing nations require an indebt understanding of some behavioural factors. The study was limited to SMEs in Lagos, Nigeria.

Original/value/contribution - The study recommends the need for managers of SMEs to monitor these three behavioural outcomes in other to ensure the sustainability of their businesses. This would in the long run, improve an employment, and reduce poverty. It also provides statistical norms for researchers.
\end{abstract}

Cite as: Adebakin, M. A., \& Okon, S. E. (2019). Procedural justice, job satisfaction and organisational citizenship behaviour within small and medium scale enterprises in Nigeria. Journal of Economics \& Management, 38(4), 5-45. https://doi.org/10.22367/jem.2019.38.01 
Keywords: procedural justice, job satisfaction, organisational citizenship behaviour (OCB), small and medium scale enterprises.

JEL Classification: I31, J28, J81, M12.

\section{Introduction}

The growing rate of poverty in Sub-Saharan Africa has been provoking the interest of all discerning minds towards efforts aimed at complete eradication of poverty. No wonder the United Nations in its 17-point Sustainable Development Goals (SDGs) direct every nation of the world to work towards zero poverty by the year 2030 (United Nations, 2015). To achieve this fit, the activities of small and medium enterprises must be reviewed for greater performance. Hence, organisational behaviour researchers have been investigating several behavioural factors which could encourage the growth of SMEs in developing nations (Ayuso, \& Navarrete-Báez, 2018; Prange \& Pinho, 2017).

Given the importance of small and medium enterprises to economic growth and development, there have been increasing rate of interest by scholars and practitioners in this sector (Rasheed, Convoy, Nadeem, \& Saddique, 2017). SMEs are seen as the backbone of any nation whether developed or developing (Qamruzzaman \& Jianguo, 2019). According to the National Bureau of Statistics (2017), Micro Small and Medium Scale Enterprises (MSMEs) in Nigeria contribute about $49.78 \%$ of the National Gross Domestic Product (GDP), and also enhances employment. Despite this, the sector still encounters several challenges which affect its performance.

Interestingly, despite the numerous studies on SMEs in Nigeria, there is a dearth of information on the role of behavioural factors on the activities of SMEs (Gorondutse \& Hilman, 2019; Ogunyomi \& Bruning, 2016). This is the main thrust of this study and seeks to investigate how procedural justice and job satisfaction may influence organisational citizenship behaviour (OCB) among employees of SMEs in Nigeria.

Although the literature has continuously shown how certain behavioural factors, such as employees' perception of fairness of procedure and outcome; employees' level of satisfaction with their jobs, and OCB, do influence efficiencies of organisations (Özduran \& Tanova, 2017).This study seeks is to provide justification for the possible link between these behavioural factors (procedural justice, job satisfaction and OCB) with a view to establishing their roles in fostering SMEs. This is important in order to provide adequate data which can assist the operations of SMEs towards ensuring their growth to enhance employment opportunities and ultimately reduce poverty in our society. 
In the opinion of Wolfe, Rojek, Manjarrer, \& Rojek (2018), the organisational justice literature concludes that how fair employees are treated has significant effect on organisational outcomes regardless of the study setting. This suggests that unfair treatment of employees has significant effect not only on the employees themselves, but on other parties (such as the workgroup and clients) within and outside the organisation (Harris, Lavelle, \& McMahan, 2018). However, the perception of justice may be triggered by various factors, one of which is the level of job satisfaction (Colquitt, 2015). Job satisfaction, which is the extent to which an employee likes or dislikes the work (Locke, 1976), is very crucial to the organisation as well as to the employee. It has grown to become a popular concept employed by researchers to help organisations achieve individual and organisational goals, for the simple reason that when employees are not satisfied with their job it becomes almost impossible to achieve other important behavioural outcomes, including organisational citizenship behaviour (Chattopadhyay, 2019). In fact, the desire by managers of organisations to hire employees, willing to go beyond the normal job requirements, has consistently provoked interest in the subject of organisational citizenship behaviour.

By definition, OCB is a set of discretionary behaviour exhibited by an employee, outside their prescribed job requirement, though not rewarded by the organisation, but has significant impact on the overall success of the organisation (Organ, 1988). Hence, organisational citizenship behaviour is a contributory factor (among others) towards the wellbeing of an organisation, be it small, medium, or large (Adebakin, Ogundele, \& Sulaimon, 2008).

The rationale for this paper's focus on small and medium enterprises is to provide a data that would aid the growth of SMEs in line with the United Nations Sustainable Development Goals (SDGs), which affirm that the growth and development of a nation largely depend on how well the SMEs function in the economy (van der Ven, 2018). There is no gainsaying the fact that SMEs remain a fundamental asset for the development of any nation. However, the numerous policies, strategies and implementation processes designed to ensure their survival in developing nations has not made noticeable impact on the sector, for the reason that less attention is paid to some behavioural factors that could foster growth in the sector (Krishnan \& Scullion, 2017). Consequently, organisational behaviour researchers have attempted to showcase the prevailing importance of organisational justice perception, job satisfaction, and OCB in modern organisations. Unfortunately, most of these studies have tilted more to large corporations in both developed and developing countries, with little attention on SMEs. This 
explains our study's focus on small and medium scale enterprise within the context of a developing country such as Nigeria.

The paper is categorised into five sections, namely the introduction, review of literature, the methodology, the results from the findings, and the conclusions.

\section{Literature review}

\subsection{OCB}

This study is anchored on the social exchange theory by Blau (1964), which beliefs the mutual relationship between two parties or groups. It advocates that a two-way relationship is expected from employees to the employer and vice versa, to avoid injustice among the parties concerned. It is obvious that when employees perceive injustice both in process and outcome, they are likely to reciprocate negatively towards the organisation. However, if the employees do not reciprocate positively after they have been fairly rewarded, the organisation will, in turn, not be happy with such employees. These two illustrations become a fundamental issue for organisations because the balance between both parties is required for the proper functioning of the organisation (Eisenberger, Huntington, Hutchison, \& Sowa, 1986). In line with this theory when procedural justice is viewed negatively by employees, it is expected that organisational citizenship behaviour will be absent in such a work setting. In the same vein, when employees are well catered for, they are likely to go beyond their call and reciprocate in a positive manner (van Knippenberg, van Prooijen, \& Sleebos, 2015).

From the days of the human relations era (1930-1939), the initiation of OCB was as a result of the satisfaction-productivity argument in the human relations era (Ocampo, Acedillo, Bacunador, Balo, Lagdameo, \& Tupa, 2018). During this era, satisfaction was viewed as a combination of innate and external factors in the work environment that gives an employee a positive feeling towards the job and the organisation (Ocampo et al., 2018). The satisfaction derived from the job by employees influences their level of organisational outcome including organisational citizenship behaviour (Organ, 1997).

According to Ocampo et al. (2018), the term OCB was coined by Bateman, \& Organ (1983). Though extra-role behaviour exhibited by employee was first observed by Katz \& Kahn (1966), but the actual definition of organisational citizenship behaviour was by Organ (1988: 4), where OCB is viewed as an "individual behaviour that is discretionary, not directly or explicitly recognised by 
the formal reward system and that in aggregate promotes the effective functioning of the organisation". Scholars have argued that this definition emanated from the work of Barnard (1968) and Katz (1964), 'individual willingness to cooperate' and 'innovative and spontaneous behaviour' of employees. Later on, Organ (1997) redefined OCB as an employee behaviour which goes beyond the standard work requirement, but helps in the proper functioning of the organisation. Since then, the definition of OCB by Organ and his associates has become the bedrock on which other definitions of OCB have hinged. Even when other scholars have come up with several definitions, all these definitions still rely on the one given by Organ and his colleagues (Ocampo et. al., 2018).

In an integrative review, Pooja, de Clercq, \& Belausteguigoitia (2016) found organisational citizenship behaviour as an important segment of human resource development which needs more attention in order to foster employee and organisational performance. Furthermore, Pradhan, Jena, \& Kumari (2016) noticed that human resource policy such as work-life balance policy has significant negative effect on employees exhibiting citizenship behaviour. The study further observed that organisational commitment mediate this relationship. Consequently, the study advised human resource practitioners to look carefully at the human resource policies of their organisations, so as to enable organisational citizenship behaviour to flourish in the organisation (Aderibigbe, Nwokolo, \& Oluwole, 2019).

A study conducted by Salas-Vallina, Alegre, \& Fernández (2017) in the health sector of Spain, found organisational learning capability impacted significantly on OCB, while new employee happiness at work mediates the relationship between organisational learning capability and organisational citizenship behaviour. Furthermore, Alfonso, Zenasni, Hodzic, \& Ripoll (2016) noticed that emotional intelligence positively impacted significantly on dimensions of OCB and this relationship was further mediated by the quality of working life among French adult teams. This study, further confirms that having a good quality of work life impacts positively on OCB of employees towards the organisation and not OCB towards the individual by employees. However, only employees with high emotional intelligence had a better quality of work life.

With data collected from 950 employees from various streams of life, van Dyne, Graham, \& Dienesch (1994) observed that certain work behaviours can only be explained through the theory-based multidimensionality measure of OCB. The study emphasised the importance of cross-discipline approach towards theory building. Furthermore, Podsakoff, Podsakoff, Mackenzie, Maynes, 
\& Spoelma (2014) in a review of OCB found that studies have focused on individual level of analysis in the earlier studies of OCB. However, a unit-level of OCB has become important as well as their outcomes today. In their review, they found that only few studies have investigated the mediators and moderators between various forms of OCB and their outcomes. Among the mediators identified by the review are group task performances, customers' satisfaction, and overall-group cohesion amongst others, while the moderators that have been employed by studies are team experience, sales experience, and organisational deviance behaviour. Despite the findings of the review, it recommended the need for further studies on the possible link between OCBs at the unit level and their outcomes.

Somech \& Drach-Zahary (2004), examining OCB from the perspective of the organisation, found that $\mathrm{OCB}$ needs to be examined as a context-related construct. It is by this arrangement that OCB benefits both the organisation and the individual. The study encourages the need for this approach for organisations to achieve better results. Halbesleben \& Bellairs (2016) examined how various motives could influence the way in which employees exhibit various forms of OCB within a given context. The review opined that OCB is viewed as the future of one's work which can be accomplished either through multi-finality or equifinality, which in the end gives an employee the best way to accomplish their goals.

Ogunyomi \& Bruning (2016) noticed that human resource practices of occupational health and safety and human capital development have a positive impact on the non-financial performance measure of SMEs, while employee performance had a direct relationship with financial measures. The study revealed that human resource management practices jointly influence the financial and non-financial performance of SMEs in Nigeria. Furthermore, Rasheed et al. (2017) studying SMEs in Pakistan, established a significant positive link between employee voice, high performance work system and innovation with employee voice moderating the relationship between high-performance work system and organisational innovation. The study emphasised the need to revisit extra role of employee's behaviour in SMEs generally to improve their level of performance. It is also important to note that Tahir \& Inuwa (2019) found that poor infrastructural facilities and insecurity are the two fundamental factors influencing the performance of micro, small and medium scale enterprises in $\mathrm{Ni}$ geria although the study was limited only to Bornu State in Nigeria. 


\subsection{Procedural justice and $\mathrm{OCB}$}

The justice literature has grown to show that employees will react negatively when there is injustice observed in the organisation. Organisational justice is the extent to which an employee believes they are fairly treated by the employer. The literature indicates three prominent measures of organisational justice (Colquit, 2015). These are distributive justice, procedural justice, and interactional justice. Distributive justice refers to how fair is the reward given to an employee based on the organisational outcomes, while the unbiased process employed to determine the outcomes is referred to as procedural justice (Moorman, 1991). Procedural justice is seen as having a direct impact on OCB and other various work outcomes such as organisational commitment, job satisfaction among others (Moorman, Blakely, \& Niehoff 1998). Interactional justice looks at how employees may have been treated in the course of the justice process employed (Moorman, 1991). The relationship between organisational justice and OCB has been documented in the literature as being positive. The literature posits that of all the dimensions of organisational justice, procedural justice has significant influence on OCB (Yadav \& Gupta, 2017).

Yadav \& Gupta (2017) in a study of 204 employees in the tourism industry found a positive relationship between procedural justice and OCB. However, the study observed that organisational trust did not mediate the relationship between procedural justice and organisational citizenship behaviour. Furthermore, within the Nigerian context, the performance of SMEs mostly relies on the human resources policies put in place, as it may hinder the organisational goals (Ogunyomi \& Bruning, 2016). Therefore, when the process employed to disseminate rewards is fair, it is expected that it will influence the citizenship behaviour of employees positively. Sequel to this postulation, this study hypothesised that:

$\boldsymbol{H}_{1}$ : Procedural justice perception among employees of SMEs will be significantly related to their level of $O C B$.

\subsection{Job satisfaction and $\mathrm{OCB}$}

The field of organisational behaviour has witnessed increase in studies of job satisfaction due to its importance and it is the frequently studied attitude which arises from the perception of how an employee views their job, whether positively or negatively (Ummah \& Athambawa, 2018). Job satisfaction is con- 
cerned with how an employee likes or dislikes the job, as a result of employee perception of the job. A study by Yadav \& Gupta (2017) revealed positive significant relationship between job satisfaction and OCB.

Appelbaum et al. (2004) employing a case study of a manufacturing plastic company observed that employees low in job satisfaction, are also low in their citizenship behaviour. The study opined the need to improve the level of employee job satisfaction in organisations. Moreover, Foot \& Tang (2008) in a study of manufacturing facilities in coastal Mississippi found a significant positive relationship between job satisfaction and OCB. The relationship was further moderated by team commitment. Drawing from the social exchange theory, it is expected that job satisfaction should enhance employees' OCB positively. Therefore, employees' job satisfaction should be positively related to OCB. In the light of this, it is expected that a higher level of employee job satisfaction will influence positively organisational outcomes. How an employee feels about the job is fundamental for the type of services the organisation may expect from such an employee (Oluwafemi \& Okon, 2018). Invariably, when employees are not satisfied with their job, they tend to restrict themselves only to the formal aspects of the job. Therefore, this study hypothesised that:

$\mathrm{H}_{2}:$ Job satisfaction among employees of SMEs will be significantly related to their level of $O C B$.

\section{Research methodology}

A cross-sectional survey design was adopted for the study. The justification for adopting this design is to understand the relationship that exists between the variable under study. The study sampled 1,420 employees randomly selected from 71 surveyed companies, drawn from the list of more than 1,000 SMEs in Lagos state using a proportionate and convenience sampling technique. Participants were duly informed of the research process and their anonymity was guaranteed. The choice of Lagos state was informed by its cosmopolitan nature coupled with the fact that it is a commercial hub of Nigeria where the majority of these SMEs operate. In addition, the choice of this sample was as a result of a further investigation which revealed that the majority of the SMEs had either folded up or changed addresses. Only the manufacturing and the service sectors were used for the study. 
A structured questionnaire was distributed amongst employees of the selected SMEs, ensuring voluntary and confidentiality of their response. The questionnaire is presented in the Appendix.

Procedural justice was measured with a 15 -item questionnaire developed by Niehoff \& Moorman (1993). The questionnaire was structured on a five-point Likert scale ranging from strongly disagree (1) to strongly agree (5). Example items were 'job decisions are made by my supervisor in an unbiased manner', 'All job decisions are applied consistently across all affected employees'. This instrument has a split-half reliability coefficient of .90.

Job satisfaction was measured using a twelve-item questionnaire designed by Hackman \& Oldham (1980), on a five-point Likert scale with question items such as 'I am very much satisfied with my job'. This measure has been applied by other studies (Mossholder, Bennett, Kemery, \& Wesolowski, 1998; Rahim \& Buntzman, 1989) and a reliability coefficient ranging from .60-.75 was established.

OCB was measured using the scale developed by Farh, Earley, \& Lin (1997). The researchers' choice of Farh et al. (1997) was because this study is basically interested in those dimensions that are universal across cultures to which this instrument provides adequate coverage. For instance, identification with the company, altruism, and conscientiousness, are dimensions that are universal in nature and had been measured previously with an internal consistency of $.87, .87$, and .82 , respectively.

The researchers found this instrument easily adaptable to the Nigerian situation having established new reliability coefficients of $.91, .89$, and .87 for procedural justice, job satisfaction, and $\mathrm{OCB}$, respectively.

In line with studies on OCB (Chattopadhyay, 1999; Kidder, 2002; Klotz, Bolino, Song, \& Stornelli, 2018), the current study controlled for age and the gender of respondents as they may confound the findings of the study.

\section{Research results}

The result of the bio-data of respondents revealed that there were 706 (49.7\%) males and $714(50.3 \%)$ females. This implies that there were more female than male in the sample size. In terms of age of the respondents, $24(1.7 \%)$ were $<18$ years, $626(44.1 \%)$ were between ages 20 -30 years, $579(40.8 \%)$ were between ages $31-40$ years, 169 (11.9\%) were between ages $41-50$ years, while $22(1.5 \%)$ were above 50 years. 
Before employing correlation and regression analyses to test the relationship amongst the study variables, the Harman's single factor analysis was employed in order to test the potential presence of common method bias in line with previous literatures (Podsakoff, Mackenzie, Lee, \& Podsakoff, 2003; Podsakoff, Mackenzie, \& Podsakoff, 2012). This is because the study employed a cross-sectional design, implying that the responses were collected at a particular period and is therefore susceptible to common method bias. The result revealed that a single factor accounted for $24 \%$ of variance, indicating that common method bias was not a problem, since it is below $50 \%$ cut off.

Table 1. Correlation matrix for all the study variables

\begin{tabular}{|l|l|l|c|}
\hline \multicolumn{1}{|c|}{ Variables } & 1 & 2 & 3 \\
\hline 1. Procedural justice & 1 & & \\
\hline 2. Job satisfaction & $.49 * *$ & 1 & \\
\hline 3. Organisational citizenship behaviour & $.41^{* *}$ & $.39 * *$ & 1 \\
\hline
\end{tabular}

** Correlation is significant at the 0.01 level.

Source: Authors' own research (2019).

The result of the correlation reveals a positive and significant relationship between all the variables (Table 1). For instance, procedural justice and job satisfaction $(\mathrm{r}=.49)$, procedural justice and OCB $(\mathrm{r}=.41)$, and job satisfaction and OCB $(\mathrm{r}=.39)$. This reveals a liner relationship exist between the study variables.

Further analysis was carried out to determine the extent to which procedural justice and job satisfaction have contributed to the amount of variance in OCB after controlling for age and gender. A hierarchical regression analysis of all the study variables was done and the result generated is summarised in Table 2.

Table 2. Hierarchical regression matrix for all the study variables

\begin{tabular}{|c|l|r|r|r|r|r|r|r|c|}
\hline Model & Variables & \multicolumn{1}{c|}{$\mathrm{B}$} & \multicolumn{1}{c|}{$\beta$} & \multicolumn{1}{c|}{$\mathrm{t}$} & $\mathrm{Sig}$ & $\mathrm{R}$ & $\mathrm{R}^{2}$ & $\mathrm{~F}$ & $\mathrm{P}$ \\
\hline \multirow{2}{*}{1} & Constant & 4.067 & & 48.549 & .000 & & & & \\
& Age & .045 & .063 & 2.239 & .025 & .119 & .014 & 10.233 & $<.05$ \\
& Gender & -.090 & -.081 & -2.890 & .004 & & & & \\
\hline \multirow{2}{*}{2} & Constant & 2.204 & & 19.806 & .000 & & & & \\
& Age & .023 & .032 & 1.320 & .187 & .518 & .269 & 129.875 & $<.05$ \\
& Gender & .047 & .043 & 1.717 & .086 & & & & \\
& *PJ & .294 & .349 & 13.289 & .000 & & & & \\
& **JS & .189 & .259 & 10.084 & .000 & & & & \\
\hline
\end{tabular}

Dependent Variable: OCB.

* Procedural Justice; ** Job satisfaction.

Source: Authors' own research (2019). 
From Table 2, the study controlled for age and gender, since the literature points to the fact that both age and gender have influence on employee's level of OCB. The result of the hierarchical regression reveals how much variance in OCB is explained by our model 1 . The value of $\mathrm{R}$ for model 1 is .119 , while the $\mathrm{R}^{2}$ is .014 indicating that $1.4 \%$ of the variation in OCB is caused by age and gender of employees and model 1 is significant $(F=10.233$; $p<.05)$. Model 2 which includes the controlled variables and the independent variables shows that the $\mathrm{R}$ for the model is .518 , while the $\mathrm{R}^{2}$ is .269 implying that $26.9 \%$ of the variation in OCB is caused by procedural justice and job satisfaction, while the remaining $73.1 \%$ is not captured by this study.

Also, the overall model 2 which includes the combined relationship between the controlled variables, procedural justice and job satisfaction on OCB was significant $(F=129.875 ; \mathrm{p}<0.05)$. Furthermore, the model 2 showed the relative contribution of each independent variable on the dependent variables. Procedural justice made the highest contribution to OCB $(\beta=.349 ; \mathrm{t}=13.289$; $\mathrm{p}<.05)$, while job satisfaction contributed the least $(\beta=.259 ; \mathrm{t}=10.084$; $\mathrm{p}<.05)$. However, both procedural justice and job satisfaction made a unique statistical contribution to the model.

\section{Discussion}

The study investigated the possible link between procedural justice, job satisfaction and OCB among employees of SMEs in Lagos, Nigeria after controlling for age and gender of respondents based on the premise that when an employee has perception of fairness of procedures in their work place, job satisfaction may set in. The combination of both perception of fairness and job satisfaction will trigger citizenship behaviour in the employee. When this happens, the organisation strives, thereby creating opportunities for more employment and reduction in poverty. Our focus is on SMEs because of the relative importance of the sector to national development.

Having controlled for age and gender in line with previous studies (Chattopadhyay, 1999; Kidder, 2002; Klotz et al., 2018), our finding revealed a significant relationship between these two demographic variables and OCB. This is particularly important because it informs the researcher of the influence which these controlled variables had on this study. Though the variance of the control variable did not account for much in the dependent variable, the level of significance is important for the current study. 
The findings showed a significant positive link between procedural justice and organisational citizenship behaviour, in line with the findings of Yadav \& Gupta (2017). However, given the nature of Nigeria as a developing nation, the role of SMEs becomes imperative if the UN target for SDGs must be achieved. According to Tahir \& Inuwa (2019), challenges of SMEs in Nigeria are abounding, implying that understanding how to enhance the performance of SMEs is fundamental. Therefore, establishing how procedural justice influences the citizenship behaviour of employees in SMEs is critical.

Moreover, the positive and significant relationship between job satisfaction and OCB corroborates the findings of Appelbaum et al. (2004), where a positive link was found between job satisfaction and OCB. It also provides support for the findings of Foot \& Tang (2008) and Ummah \& Athambawa (2018). Job satisfaction is a job attitude that may impede organisational outcomes because what employees feel about their job has implication for their attitude towards the job. Nonetheless, employees will be willing to go the extra mile for the organisation when they feel satisfied with their job as their happiness towards the job will naturally lead to citizenship behaviour (Salas-Vallina et al., 2016).

It is worth noting that in line with the social exchange theory, employees will decide to give their best when they see and feel the norm of mutual benefit from the employers. SME owners must recognise that an employee's positive feeling about the job is essential for such an employee going the extra mile for the organisation. In addition, understanding what makes an employee give his or her best to the organisation in line with the social exchange theory should be considered.

\section{Conclusions}

The importance of behavioural factors has continued to be relevant to organisations' success and ultimate survival. On the one hand, the study found a positive link between procedural justice and $\mathrm{OCB}$, and on the other, between job satisfaction and OCB, even after controlling for age and gender for both procedural justice and job satisfaction. This study therefore concludes that procedural justice and job satisfaction influence the citizenship behaviour among employees in Nigerian SMEs. The study affirms the importance of the perception of employees' job attitude and work outcomes. It becomes important that organisations endeavour to promote better relationship between employees and their employers in line with the social exchange theory. 


\subsection{Research contributions}

The study contributes to the existing literature on behavioural factors that affects the growth of SMEs in developing countries. Paying adequate attention to these factors can help sustain SMEs, which in the long run can help reduce the level of poverty and unemployment. Within the Nigerian context studies on SMEs have investigated how government policies, their implementation, and human resource practices have affected the performance of SMEs (Ogunyomi \& Bruning, 2016; Tahir \& Inuwa 2019). However, this study differs to the extent that it examined the influence of procedural justice and job satisfaction on the citizenship behaviour of SME employees. It therefore becomes imperative to understand how procedural justice, job satisfaction and OCB can help enhance the performance of SMEs in developing nations. Since SMEs are seen as the major driver to unlock the economy, it becomes imperative that adequate attention should be paid to this critical sector.

\subsection{Research implications}

Our findings have serious implications for organisations who desire to remain in business. This study re-emphasises the importance of employees' perception of justice, what they feel, do, or even think about their job and their organisation as well as their citizenship behaviour as necessary antecedents for organisations' growth and success.

The study therefore recommends that employers of labour in the small and medium scale industry should imbibe fairness in the procedure of activities, especially the human resource activities, employed in their respective organisations. Employers must also create an enabling work environment that will promote job satisfaction and citizenship behaviour. Government should embark on massive campaign among SMEs (using experts in organisational behaviour) on the need to understand the role of behavioural factors in the success of their businesses. Policies on small and medium scale enterprises should be implemented and monitored to minimise deviation from the required standard. 


\subsection{Research limitations and future research}

The current study was limited to Lagos state, Nigeria. Further studies can be conducted in other states of the federation to give room for wider coverage and possible generalisation. Studies can also be conducted in other developing countries to ascertain the findings of the current study. The cross-sectional research design used in this study is also a limitation. Future studies can employ a longitudinal research design. The role of other behavioural factors such as counterproductive work behaviour, employee commitment, and employee engagement on activities of SMEs in developing nations should be investigated.

\section{Appendix}

\section{Survey Questionnaire}

Dear Sir/Madam

The researcher is currently conducting a study on 'procedural justice, job satisfaction and organisational citizenship behaviour among employees of small and medium enterprises in Lagos'. The purpose of this questionnaire is to gather data necessary for determining the relationship between the variables with a view to assisting small and medium enterprises in Nigeria towards achieving maximum efficiency and enhanced productivity.

Kindly assist in completing the questionnaire with all honesty and sincerity of purpose. We assure you that all responses shall be treated with maximum confidentiality and respect for your opinion.

Thank you for your assistance.

Researchers

Section A: Background Information of Respondent

Gender:

$$
\text { Male [ ] Female [ ] }
$$

What is your age range? :

\begin{tabular}{|c|c|}
\hline$<18 \mathrm{yrs}$ & {[} \\
\hline $20-30 \mathrm{yrs}$ & \\
\hline $31-40$ yrs & \\
\hline $41-50 \mathrm{yrs}$ & \\
\hline
\end{tabular}




\section{Section B: Procedural Justice and Organizational Citizenship Behaviour}

Please carefully read each descriptive statement, thinking in terms of your supervisor, job and organisation. Please circle the number which most closely responds to your thinking.

Strongly disagree - 1; Disagree - 2; Uncertain - 3; Agree - 4; Strongly agree - 5

\begin{tabular}{|c|c|c|c|c|c|}
\hline Questions & 1 & 2 & 3 & 4 & 5 \\
\hline $\begin{array}{l}\text { 1. Job decisions are made by supervisors/managers in an unbiased } \\
\text { manner }\end{array}$ & & & & & \\
\hline $\begin{array}{l}\text { 2. Supervisors/managers make sure that all employee concerns are } \\
\text { heard before job decisions are made }\end{array}$ & & & & & \\
\hline $\begin{array}{l}\text { 3. Supervisors/managers collect accurate and complete infor- } \\
\text { mation to make job decisions }\end{array}$ & & & & & \\
\hline $\begin{array}{l}\text { 4. Supervisors/managers clarify decisions and provide additional } \\
\text { information when requested by employees }\end{array}$ & & & & & \\
\hline $\begin{array}{l}\text { 5. All job decisions are applied consistently across all affected } \\
\text { employees }\end{array}$ & & & & & \\
\hline $\begin{array}{l}\text { 6. Supervisors/managers allow employees to challenge or appeal } \\
\text { job decisions }\end{array}$ & & & & & \\
\hline $\begin{array}{l}\text { 7. When decisions are made about jobs, supervisors/managers treat } \\
\text { employees with kindness and consideration }\end{array}$ & & & & & \\
\hline $\begin{array}{l}\text { 8. When decisions are made about jobs, supervisors/managers treat } \\
\text { employees with respect and dignity }\end{array}$ & & & & & \\
\hline $\begin{array}{l}\text { 9. When decisions are made about jobs, supervisors/managers } \\
\text { are sensitive to employees' personal needs }\end{array}$ & & & & & \\
\hline $\begin{array}{l}\text { 10. When decisions are made about jobs, supervisors/managers deal } \\
\text { with employees in a truthful manner }\end{array}$ & & & & & \\
\hline $\begin{array}{l}\text { 11. When decisions are made about jobs, supervisors/managers } \\
\text { show concern for the rights of employees }\end{array}$ & & & & & \\
\hline $\begin{array}{l}\text { 12. Concerning decisions made about jobs, supervisors/managers } \\
\text { discuss the implications of the decisions with employees }\end{array}$ & & & & & \\
\hline $\begin{array}{l}\text { 13. Supervisors/managers offer adequate justifications to employees } \\
\text { for decisions made about jobs }\end{array}$ & & & & & \\
\hline $\begin{array}{l}\text { 14. When making decision about job the supervisors/managers offer } \\
\text { explanation that make sense to the employees }\end{array}$ & & & & & \\
\hline $\begin{array}{l}\text { 15. Supervisors/managers explain very clearly any decision made } \\
\text { about jobs }\end{array}$ & & & & & \\
\hline 16. I am willing to stand up to protect the reputation of the company & & & & & \\
\hline 17. I am eager to tell outsiders good news about the company & & & & & \\
\hline $\begin{array}{l}\text { 18. I make constructive suggestions that can improve the operation } \\
\text { of the company }\end{array}$ & & & & & \\
\hline 19. I actively attend company meeting & & & & & \\
\hline $\begin{array}{l}\text { 20. I am willing to assist new colleagues to adjust to the work } \\
\text { environment }\end{array}$ & & & & & \\
\hline 21. I am willing to help colleagues solve work-related problems & & & & & \\
\hline
\end{tabular}




\begin{tabular}{|c|c|c|c|c|c|}
\hline Questions & 1 & 2 & 3 & 4 & 5 \\
\hline $\begin{array}{l}\text { 22. I am willing to cover work related assignment for colleagues } \\
\text { when needed }\end{array}$ & & & & & \\
\hline 23. I am willing to coordinate and communicate with colleagues & & & & & \\
\hline $\begin{array}{l}\text { 24. I comply with company rules and regulations even when } \\
\text { nobody watches and no evidence can be traced }\end{array}$ & & & & & \\
\hline 25. I take my job seriously and rarely make mistakes & & & & & \\
\hline 26. I do not mind taking on new challenging assignments & & & & & \\
\hline 27. I try hard to self-study to increase the quality of work output & & & & & \\
\hline 28. I often arrive early and start to work immediately & & & & & \\
\hline
\end{tabular}

Key: Q1-Q14 Measures of Procedural Justice - (Niehoff \& Moorman, 1993).

Q15-Q28 Measures of Organizational Citizenship Behaviour (Farh, Earley, \& Lin, 1997).

Section C - Job Satisfaction Items (Hackman \& Oldham, 1980)

The statements below indicate how satisfied you are with each of your job postings. Kindly tick the option which most closely corresponds to your thinking about your job.

Extremely dissatisfied - 1; Dissatisfied - 2; $\quad$ Neutral $-\mathbf{3}$; Satisfied $-\mathbf{4}$; Extremely satisfied $-\mathbf{5}$

\begin{tabular}{|c|c|c|c|c|c|}
\hline Questions & 1 & 2 & 3 & 4 & 5 \\
\hline \multicolumn{6}{|l|}{ The amount of job security I have } \\
\hline \multicolumn{6}{|l|}{ The amount of pay and fringe benefits I receive } \\
\hline \multicolumn{6}{|l|}{$\begin{array}{l}\text { The amount of personal growth and development } \\
\text { I get in doing my job }\end{array}$} \\
\hline \multicolumn{6}{|l|}{ The degree of respect and fair treatment I receive from my boss } \\
\hline \multicolumn{6}{|c|}{ The feeling of worthwhile accomplishment I get from doing my job } \\
\hline \multicolumn{6}{|l|}{ The amount of support and guidance I receive from my supervisor } \\
\hline \multicolumn{6}{|l|}{$\begin{array}{l}\text { The degree to which I am fairly paid for what } \\
\text { I contribute to this organisation }\end{array}$} \\
\hline \multicolumn{6}{|l|}{$\begin{array}{l}\text { The amount of independent thought and action } \\
\text { I can exercise in my job }\end{array}$} \\
\hline \multicolumn{6}{|l|}{ How secure things look for me in the future in this organisation } \\
\hline \multicolumn{6}{|l|}{ The chance to help other people while at work } \\
\hline \multicolumn{6}{|l|}{ The amount of challenge in my job } \\
\hline The overall quality of the supervision I receive in my work & & & & & \\
\hline
\end{tabular}




\section{References}

Adebakin, M. A., Ogundele, O. J., \& Sulaimon, A. A. (2008). Effect of job satisfaction and organisational commitment on organisational citizenship behaviour. Proceedings of African Regional Conference on Sustainable Development, 1(1), 21-28.

Aderibigbe, J. K., Nwokolo, E. E., \& Oluwole, O. J. (2019). Effect of psychosocial factors on organisational citizenship behavior among graduate employees in Nigeria. Economics and Sociology, 12(1), 155-367. https://doi.org/10.14254/2071-789X.2019 $/ 12-1 / 9$

Alfonso, L., Zenasni, F., Hodzic, S., \& Ripoll, P. (2016). Understanding the mediating role of quality of work life on the relationship between emotional intelligence and organisational citizenship behaviors. Psychological Reports, 118(1), 107-127. https://doi.org/10.1177/0033294115625262

Appelbaum, S., Bartolomucci, N., Beaumier, E., Boulanger, J., Corrigan, R., Dore, I., \& Serroni, C. (2004). Organisational citizenship behavior: A case study of culture, leadership and trust. Management Decision, 42(1), 13-40. https://doi.org/10. $1108 / 00251740410504412$

Ayuso, S., \& Navarrete-Báez, F. E. (2018). How does entrepreneurial and international orientation influence SMEs' commitment to sustainable development? Empirical evidence from Spain and Mexico. Corporate Social Responsibility and Environmental Management, 25(1), 80-94. https://doi.org/10.1002/csr.1441

Barnard, C. I. (1968). The functions of the executive. Cambridge, MA: Harvard University Press.

Bateman, T. S., \& Organ, D. W. (1983). Job satisfaction and the good soldier: The relationship between affect and employee "citizenship". Academy of Management Journal, 26(4), 587-595. https://doi.org/10.5465/255908

Blau, P. M. (1964). Justice in social exchange. Sociological Inquiry, 34(2), 193-206. https://doi.org/10.1111/j.1475-682X.1964.tb00583.x

Chattopadhyay, P. (1999). Beyond direct and symmetrical effects: The influence of demographic dissimilarities on organisational citizenship behavior. Academy of Management Journal, 42(3), 273-287. https://doi.org/10.5465/256919

Chattopadhyay, R. (2019). Impact of force distribution system on performance evaluation on organisational citizenship behavior. Global Business Review, 20(3), 826837. https://doi.org/10.1177/0972150917721819

Cohen-Charash, Y., \& Spector, P. E. (2001). The role of justice in organizations: A meta-analysis. Organisational Behavior and Human Decision Processes, 86, 278-321. https://doi.org/10.1006/obhd.2001.2958

Colquitt, J. A. (2001). On the dimensionality of organisational justice: A construct validation of a measure. Journal of Applied Psychology, 86(3), 386-400. https://doi:10.1037//0021-9010.86.3.386 
van Dyne, L., Graham, J. W., \& Dienesch, R. M. (1994). Organisational citizenship behavior: Construct redefinition, measurement, and validation. Academy of Management Journal, 37(4), 765-802. https://doi.org/10.5465/256600

Eisenberger, R., Huntington, R., Hutchison, S., \& Sowa, D. (1986). Perceived organisational support. Journal of Applied Psychology, 71(3), 500-507. https://doi.org/ 10.1037/0021-9010.71.3.500

Farh, J. L., Earley, P. C., \& Lin, S. C. (1997). Impetus for action: A cultural analysis of justice and organisational citizenship behaviour in Chinese society. Administrative Science Quarterly, 42(3),421-444. https://doi.org/10.2307/2393733

Foot, D. A., \& Tang, T. L.-P. (2008). Job satisfaction and organisational citizenship behavior (OCB): Does team commitment make a difference in self-directed team. Management Decision, 46(6), 933-947. https://doi.org/10.1108/00251740810882680

Gorondutse, A. H., \& Hilman, H. (2019). Does organisational culture matter in the relationship between trust and SMEs performance. Management Decision, 57(7), 16381658. https://doi/10.1108/MD-05-2018-0557

Hackman, J. R., \& Oldman, G. R. (1980). Work redesign. Reading, MA: Addison.

Halbesleben, J., \& Bellairs, T. (2016). What are the motives for employees to exhibit citizenship behaviour? A review of prosocial and instrumental predictors of organisational citizenship behaviour. In Ph. M. Podsakoff, S. B. Mackenzie, \& N. P. Podsakoff (Eds.), The Oxford handbook of organisational citizenship behaviour (pp. 1-31). https://doi.org/10.1093/oxfordhb/9780190219000.013.16

Harris, C. M., Lavelle, J. J., \& McMahan, G. C. (2018). The effects of internal and external sources of justice on employee turnover intention and organisational citizenship behaviour toward clients and workgroup members. The International Journal of Human Resource Management, 1-24. https://doi.org/10.1080/09585192.2018. 1441163

Katz, D. (1964). Motivational basis of organisational behavior. Behavioral Science, 9(2), 131-146. https://doi.org/10.1002/bs.3830090206

Katz, D., \& Kahn, R. L. (1966). The social psychology of organizations. New York, NY: Wiley.

Kidder, D. L. (2002). The influence of gender on performance of organisational citizenship behaviour. Journal of Management, 28(5), 629-648. htts://doi.org/10. 1177/014920630202800504

Klotz, A. C., Bolino, M. C., Song, H., \& Stornelli, J. (2018). Examining the nature, causes, and consequences of profiles of organisational citizenship behaviour. Journal of Organisational Behaviour, 39(5), 629-647. https://doi.org/10.1002/job.2259

van Knippenberg, D., van Prooijen, J. W., \& Sleebos, E. (2015). Beyond social exchange: Collectivism's moderating role in the relationship between perceived organisational support and organisational citizenship behaviour. European Journal of Work and Organisational Psychology, 24(1), 152-160. https://doi.org/10.1080/ 1359432X.2013.858699 
Krishnan, T. N., \& Scullion, H. (2017). Talent management and dynamic view of talent in small and medium enterprises. Human Resource Management Review, 27(3), 431-441. https://doi.org/10.1016/j.hrmr.2016.10.003

Locke, E. A. (1976). The nature and cause of job satisfaction. In M. D. Dunnette (Ed.), Handbook of Industrial and Organisational Psychology (Vol. 1, pp. 1297-1343). Chicago: Rand McNally.

Moorman, R. H. (1991). Relationship between organisational justice and organisational behaviours: Do fairness perceptions influence employee citizenship. Journal of Applied Psychology, 76(6), 845-855. https://dx.doi.org/10.1037/0021-9010.76.6.845

Moorman, R. H., Blakely, G. L., \& Niehoff, B. P. (1998). Does perceived organisational support mediate the relationship between procedural justice and organisational citizenship behaviour? Academy of Management Journal, 41(3), 351-357. https:// doi.org/10.5465/256913

Mossholder, K. W., Bennett, N., Kemery, E. R., \& Wesolowski, M. A. (1998). Relationships between bases of power and work reactions: The mediational role of procedural justice. Journal of Management, 24(4), 533-552. https://doi.org/10.1177/ 014920639802400404

National Bureau of Statistics. (2017). National survey of micro small \& medium enterprises (MSMEs) 2017. Retrieved July 20, 2019 from https://www.nigerianstat. gov.ng

Niehoff, B. P., \& Moorman, R. H. (1993). Justice as a mediator of the relationship between methods of monitoring and organisational citizenship behaviour. Academy of Management Journal, 36(3), 527-556. https://doi.org/10.5465/256591

Ocampo, L., Acedillo, V., Bacunador, A. M., Balo, C. C., Lagdameo, Y. J., \& Tupa, N. S. (2018). A historical review of the development of organisational citizenship behaviour (OCB) and its implication for the twenty-first century. Personnel Review, 47(4), 821-862. https://doi.org/10.1108/PR-04-2017-0136

Ogunyomi, P., \& Bruning, N. S. (2016). Human resource management and organisational performance of small and medium enterprises (SMEs) in Nigeria. The International Journal of Human Resource Management, 27(6), 612-634. https:// doi.org/10.1080/09585192.2015.1033640

Oluwafemi, O. J., \& Okon, S. E. (2018). The nexus between total quality management, job satisfaction and employee work engagement in the food and beverage multinational company in Nigeria. Organisations and Markets in Emerging Economies, 9(2), 251-271. https://doi.org/10.15388/omee.2018.10.00013

Organ, D. W. (1988). Organisational citizenship behavior: The good soldier syndrome. Lexington, MA: Lexington Books.

Organ, D. W. (1997). Organisational citizenship behaviour: It's construct clean-up time. Human Performance, 10(2), 85-97. https://doi.org/10.1207/s15327043hup1002_2

Özduran, A., \& Tanova, C. (2017). Coaching and employee organisational citizenship behaviours: The role of procedural justice climate. International Journal of Hospitality Management, 60, 58-66. https://doi.org/10.1016/j.ijhm.2016.10.004 
Podsakoff, P. M., Mackenzie, S. B., Lee, J., \& Podsakoff, N. P. (2003). Common method biases in behavioural research: A critical review of the literature and recommended remedies. Journal of Occupational and Organisational Psychology, 88(5), 879-903. https://doi:10.1037/0021-9010.88.5.879

Podsakoff, P. M., MacKenzie, S. B., \& Podsakoff, N. P. (2012). Sources of method bias in social science research and recommendations on how to control it. Annual Review of Psychology, 63, 539-569. https://doi.org/10.1146/annurev-psych-120710100452

Podsakoff, N. P., Podsakoff, P. M., MacKenzie, S. B., Maynes, T. D., \& Spoelma, T. M. (2014). Consequences of unit-level organisational citizenship behaviors: A review and recommendations for future research. Journal of Organisational Behaviour, 35(1), 87-119. https://doi.org/10.1002/job.1911

Pooja, A. A., de Clerccq, D. D., \& Belausteguigoitia, I. (2016). Job stressors and organisational citizenship behavior: The role or organisational commitment and social interaction. Human Development Quarterly, 27(3), 373-405. https://doi.org/ 10.1002/hrdq. 21258

Pradhan, R. K., Jena, L. K., \& Kumari, I. G. (2016). Effect of work-life balance on organisational citizenship behavior: Role of organisational commitment. Global Business Review, 17(3), 15S-29S. https://doi.org/10.1177/0972150916631071

Prange, C., \& Pinho, J. C. (2017). How personal and organisational drivers impact on SME international performance: The mediating role of organizational innovation. International Business Review, 26(6), 1114-1123. https://doi.org/10.1016/j.ibusrev. 2017.04.004

Qamruzzaman, M., \& Jianguo, W. (2019). SME financing innovation and SME development in Bangladesh: An application of ARDL. Journal of Small Business \& Entrepreneurship, 31(6), 521-545. https://doi.org/10.1080/08276331.2018.1468975

Rahim, M. A., \& Buntzman, G. F. (1989). Supervisory power bases, styles of handling conflict with subordinates, and subordinate compliance and satisfaction. The Journal of Psychology, 123(2), 195-210. https://doi.org/10.1080/00223980.1989. 10542976

Rasheed, M. A., Shahzad, K., Conroy, C., Nadeem, S., \& Siddique, M. U. (2017). Exploring the role of employee voice between high-performance work system and organisational innovation in small and medium enterprises. Journal of Small Business and Enterprise Development, 24(4), 670-688. https://doi.org/10.1108/JSBED -11-2016-0185

Salas-Vallina, A., Alegre, J., \& Fernández, R. (2017). Organisational learning capability and organisational citizenship behaviour in the health sector: Examining the role of happiness at work from a gender perspective. International Journal of Health Planning and Management, 32(2), 137-159. https://doi.org/10.1002/hpm.2363

Somech, A., \& Drach-Zahavy, A. (2004). Exploring organisational citizenship behaviour from an organisational perspective: The relationship between organisational learning and organisational citizenship behaviour. Journal of Occupational and Organisational Psychology, 77(3), 281-298. https://doi.org/10.1348/0963179041752709 
Tahir, F. A., \& Inuwa, F. U. (2019). Empirical investigation of the factors affecting micro, small and medium scale enterprises performance in Borno State, Nigeria. International Business Research, 12(4), 30-39. https://doi.org/10.5539/ibr.v12n4p30

Ummah, S., \& Athambawa, S. (2018). Organisational citizenship behavior and job satisfaction among non-academic employees of national universities in the Eastern province of Sri Lanka. American Journal of Economics and Business Management, 1(1), 75-84. https://doi.org/10.31150/ajebm.v1i1.8

United Nations. (2015). Transforming our world: The 2030 agenda for sustainable development. New York. Retrieved from https://sustainabledevelopment.un.org /post2015/transformingourworld

van der Ven, C. M. (2018). Inclusive industrialization: The interplay between investment incentives and SME promotion policies in Sub-Saharan Africa. Law and Development Review, 11(2), 557-587. https://doi.org/10.1515/ldr-2018-0029

Wolfe, S. E., Rojek, J., Manjarrez, V. M. Jr, \& Rojek, A. (2018). Why does organisational justice matter? Uncertainty management among law enforcement officers. Journal of Criminal Justice, 54, 20-29. https://doi.org/10.1016/j.jcrimjus. 2017.11.003

Yadav, L. K., \& Gupta, P. (2017). Procedural justice, job satisfaction and organisation citizenship behavior: Mediating role organisation trust-India tourism industry study. Management and Labour Studies, 42(3), 275-292. https://doi.org/10.1177/ $0258042 \mathrm{X} 17718738$ 